\title{
TOXICITY POTENTIAL IN THE EXTRANEOUS COMPOUNDS OF WHITE MULBERRY WOOD (Morus alba)
}

\author{
Aida Se Golpayegani 1,2,^, Marie- France Thévenon ${ }^{1}$, Joseph Gril'2, \\ Eric Masson ${ }^{3}$, Kambiz Pourtahmasi ${ }^{4}$
}

In memoriam of Dr. Manfred SCHWANNINGER

\begin{abstract}
The health problems amongst musical instrument makers working on the White mulberry (Morus $a l b a$ ), lead to investigate the toxicity potential of wood extractives. Five solvents of different polarity and two methods of extractions were used to ensure a thorough, clear and classified compound removal. The compounds were identified using qualitative GC-mass and the toxicity were determined by studying their effect on termite survival (Reticulitermes flavipes). The results indicated the presence of different compound categories like phenols, higher hydrocarbons, fatty acids, sterols and aromatic components in the extractives. These compounds were not removable by just one solvent and the order of removal was polarity related. The extractives were found toxic towards termites. Resorcinol, which corresponded to the highest proportion of peaks in the GC-mass spectra, has been assigned as the possible compound responsible for the allergic reactions by the artisans.
\end{abstract}

Keywords: White mulberry, extractives, decay resistance, toxicity, GC-mass, Reticulitermes flavipes.

\section{INTRODUCTION}

White mulberry heartwood (Morus alba) is the main source for crafting the three traditional longnecked lutes in Iran. Even though it has been the only choice of artisans for centuries, the process of making these instruments have always brought health problems upon the makers. There are undocumented statements of this wood causing allergic reaction like breathlessness, sever coughs and headache among the craftsmen. The severity of the situation has sometimes resulted in the instrument makers to quit working on this particular wood, despite its high acoustic qualities for music instruments. Regardless of all the problems during the fabrication, the completed instrument is harmless in the hands of players. This leads to the hypothesis that the irritation is caused by the secondary metabolites (extractives) present in the wood matrix and released throughout the fabrication process.

The chemical structure of wood is composed not only of its primary constituents, but also of a relatively small fraction of mostly extractable compounds. Extractives can include different categories like phenols, tannins and oils. The primary role of these materials is to protect the tree and timber against decay agents; therefore it is quite expected that they would have termiticidal, fungicidal and even toxic properties. Conceptually, heartwood extractives play a significant role in protecting the wood from decay organisms (Hillis 1962, Highley and Scheffer 1970, Tsunoda 1990, Schultz and Nicolas 2000, Taylor et al. 2002).

\footnotetext{
${ }^{1}$ Production et valorisation des bois tropicaux et méditerranéens, CIRAD, TA B40/16, 34398 Montpellier Cedex 5, France

${ }^{2}$ Laboratoire de Mécanique et Génie Civil (LMGC), Université Montpellier 2, CNRS UMR5508, Place E. Bataillon, cc 048, 34095 Montpellier Cedex 5, France

${ }^{3}$ CRITT Bois, 27 rus Philippe Seguin, BP 91067, 88051 Epinal Cedex 9, France

${ }^{4}$ Department of Wood and Paper Science and Technology, Faculty of Natural Resources, University of Tehran, Tehran, Iran

^Corresponding author: e-mail: aida.golpayegani@gmail.com

Received : 16.02. 2013 Accepted : 16.09. 2013.
} 
Attempts to estimate the toxicity potential of extractives are made to find naturally active ingredients for wood and material preservation (Turner and Conradie 1995, Croan and Haight 2001, Thevenon et al. 2003, Arango et al. 2006, El hanbali et al. 2007, Ragon et al. 2008). However, the protecting role cannot always be assigned to one particular compound and often synergetic effects are involved (Hwang et al. 2007).

White Mulberry being traditionally recognized as a medicinal species and its leaves being the food of the silk, there are extensive reports on the leaves or root-bark extracts of white mulberry (Chen and Li 2007, Yatsunami et al. 2008, Nakamura et al. 2009, Piao et al. 2009, Zheng et al. 2010). The wood is also been reported to be durable (Se Golpayegani et al. 2010, Se Golpayegani 2011). Compounds present in the extractives of white mulberry wood were previously reported by Venkataraman (1972), Rowe and Conner (1979), Se Golpayegani (2007) and Sadeghifar et al. (2011). Generally a combination of phenols, stilbenes, flavonoids and sterols has been reported, but the full variety of the components or their possible toxic potentials have not been investigated to date.

This work aims at identifying the compounds acting as active ingredients for durability towards termites, and therefore potentially responsible for the health problems experienced by musical instrument makers. For that, two methods of extractions by five solvents of various polarities (Se Golpayegani et al. 2011) were used to allow a more classified and definite compound removal. Qualitative GC-Mass tests were carried out to identify the components removed in each phase. For toxicity test, the removed extracts and their corresponding extracted powders were exposed to the attack of termites and the survival rates were monitored. Finally, by correlating the GC-Mass spectra to the survival rate of the termites the possible compound(s) responsible for allergic reactions by the artisans were identified.

\section{MATERIALS AND METHODS}

\section{Materials}

Heartwood samples of White mulberry (Morus alba L.) have been prepared with the help of a famous Iranian instrument maker (Mr. Samad Zare, a professional lute maker) to ensure the similarity with wood used for musical instruments. The wood was grounded to fine powder using a Retsh rotating-knife grinder (SM 100). Final powder with particle size $<0,5 \mathrm{~mm}$ (Tappi standard method (T207-cm)) was then produced, allowing a second grounding by a Retsh ultra-centrifugal mill (ZM 200). The powder was oven dried at $60^{\circ} \mathrm{C}$ for $48 \mathrm{~h}$ and then conditioned for one week in a climatic chamber $(65 \pm 5 \% \mathrm{RH}$, $20 \pm 2^{\circ} \mathrm{C}$ ) before being subjected to extraction procedures.

\section{Methods}

\section{Extractions}

Five solvents of increasing polarity were used for extractions: Hexane (HX), Dichloromethane (DM), Acetone (AC), Methanol (ME) and hot water $\left(\mathrm{HW}\right.$ at $\left.100^{\circ} \mathrm{C}\right)$. The most used were Soxhlet extractors. Extractions were done in two ways: independent (parallel) and successive (serial). The independent method consisted in exposing 5 individual sets of samples to 5 solvents separately, while in the successive process, one sample is submitted to extraction by all 5 solvents with respect to their polarity (i.e. starting from $\mathrm{HX}$ and continuing subsequently with $\mathrm{DM}, \mathrm{AC}, \mathrm{ME}$ and $\mathrm{HW}$, leading to obtain so-called cumulated extractives ) (Se Golpayegani et al. 2011). Through the procedure, $3 \mathrm{~g}$ of wood powder was extracted for $8 \mathrm{~h}$ in a cellulose cartridge, and then oven dried $\left(60^{\circ} \mathrm{C}\right.$ for $\left.48 \mathrm{~h}\right)$ to measure the yield of extraction. The cumulated extractives were gathered after solvent evaporation. Both extracted powders and their respective cumulated extractives were kept for further analysis. 


\section{GC-Mass}

\section{Gas chromatography}

Analyses were done by coupling gas chromatography and mass spectrometry (Both from Clarus ${ }^{\circledR}$ PerkinElmer Inc., USA), where the column used was a fused silica capillary (5\% diphenyl and 95\% dimethyl polysiloxane). The Elite column- $5 \mathrm{~ms}$ was of $60 \mathrm{~m} \times 0,25 \mathrm{~mm}$ dimensions with a film of $0,25 \mu \mathrm{m}$ thickness (PerkinElmer Inc., USA). Helium was used as the carrier gas (Alpha gaz2, Air Liquide, France) at the constant flow rate of $1 \mathrm{ml} \mathrm{min}^{-1}$. Injection was done in the splitless mode for $0,5 \mathrm{~min}$ then at the spit flow rate of $50 \mathrm{ml} \mathrm{min}^{-1}$. First $0,5 \mu l$ was injected at $250^{\circ} \mathrm{C}$. The oven was programmed at $35^{\circ} \mathrm{C}(8$ $\min$ ) to $345^{\circ} \mathrm{C}$ (at the rate of $5^{\circ} \mathrm{C} \mathrm{min}^{-1}$ ). Before finishing the procedure, the temperature remained stable at $345^{\circ} \mathrm{C}$ for $10 \mathrm{~min}$.

The GC-Mass tests were done twice: once on the crude extracts and then on the derived ones. Compounds were identified through computer comparison of the mass spectra to those in the Wiley library by mass fragmentography and also by comparison with standard compounds.

\section{Preparing BSTFA derivations}

The extracted compounds were derived with N, O-bis-(trimethylsilyl) trifluoroacetamide containing $1 \%$ trimethylchlorosilane (BSTFA / 1\% v/v TMCS) (Acros Organics ${ }^{\circledR}$ ) and then analyzed by GC/MS coupling as follows: $0,2 \mathrm{ml}$ of BSTFA / 1\% TMCS $+0,4 \mathrm{ml}$ of acetonitrile (Fisher Scientific) were added to $5 \mathrm{mg}$ of dry extract and the mixture was stirred before being heated to $70^{\circ} \mathrm{C}$ for $30 \mathrm{~min}$. After cooling, the extract was transferred to a secondary injection vial and then analyzed.

\section{Mass spectrometry}

Mass spectrometry was performed by an electronic ionization with the energy of $70 \mathrm{eV}$. Temperature of the ion trap and the transfer line were set to $250^{\circ} \mathrm{C}$ and $330^{\circ} \mathrm{C}$ respectively. Detection was done in scan mode (ions of 20-500 $\mathrm{m} \mathrm{z}^{-1}$ ) and the analysis started 10 min after the injection.

\section{Toxicity tests against termites}

Toxicity tests were done on both extracted powders and remaining extracts of each respective solvent.

\section{Toxicity of extracted powder}

Samples were all dried at $103^{\circ} \mathrm{C} \pm 2^{\circ} \mathrm{C}$ before introducing to Petri dishes. For each set of experiment, Petri dishes were filled with $0,2 \mathrm{~g}$ powder (not-extracted powder and that extracted by each solvent independently), $30 \mathrm{~g}$ of wet Fontainebleau sand (sand/water volume 4:1) and 30 termites (all workers from Reticulitermes flavipes ex. santonensis). In addition to the actual samples, two types of controls were prepared: termites were kept in dishes containing (1) only sand (diet) and (2) 0,2 g of fine Scot pine sapwood powder (control).

\section{Toxicity of cumulated extractives}

$15 \mu \mathrm{l}$ of each removed extractive mixed with its respective solvent (i.e. removed extractives after HX extraction mixed in their HX solution, those separated by DM with DM and so on) was added to a cellulosic paper of $1 \mathrm{~cm}^{2}$ in the middle of a Petri dish containing 30 termites (same as before). Controls were prepared in the form of solvent treated papers (papers treated by each solvent individually without the extractives) as well as diet ones.

For both extractives and powders, triplicate dishes were made. Samples were kept in the dark at 27 $\pm 1^{\circ} \mathrm{C}, 70 \pm 5 \% \mathrm{RH}$, for 30 days. Termites survival was checked every day. Dead termites were removed to prevent cannibalism and contamination. At the end of this period, the results were analyzed and presented in forms of means and standard deviations based on survival rate of termites, their activity, and surface loss of the paper (for extractives). 


\section{RESULTS AND DISCUSSION}

\section{Compound identification}

The qualitative GC-Mass test on crude and siloxane-derived extractives of white mulberry wood resulted in identifying a combination of higher hydrocarbons (from $\mathrm{C}_{18}$ to $\mathrm{C}_{33}$ ), fatty acids (from Tetradecanoic to Tricosanoic acid), phenols, aromatic compounds and sterols (Table 1).

Table1. Identified Compounds in the Extractives of White Mulberry Wood Removed by Five Solvents.

\begin{tabular}{|c|c|c|c|c|c|c|c|}
\hline Compound & Formula & $\begin{array}{c}\text { MW } \\
\left(\mathrm{g} \mathrm{mol}^{-1}\right)\end{array}$ & $\begin{array}{c}\text { RT } \\
(\text { HX) } \\
\text { (min) }\end{array}$ & $\begin{array}{c}\text { RT } \\
\text { (DM) } \\
(\mathrm{min})\end{array}$ & $\begin{array}{c}\text { RT } \\
(A C) \\
(\min )\end{array}$ & \begin{tabular}{c|} 
RT \\
(ME) \\
$(\min )$
\end{tabular} & $\begin{array}{c}\text { RT } \\
(H W) \\
(\min )\end{array}$ \\
\hline \multicolumn{8}{|c|}{ Higher hydrocarbons" } \\
\hline Octadecane & $\mathrm{C}_{18} \mathrm{H}_{44}$ & 254,50 & 42,24 & - & - & - & - \\
\hline Nonadecane & $\mathrm{C}_{19} \mathrm{H}_{40}$ & 268,53 & 44,28 & 44,26 & - & - & - \\
\hline Heneicosane & $\mathrm{C}_{21} \mathrm{H}_{44}$ & 296,58 & 48,05 & 48,02 & - & - & - \\
\hline Docosane & $\mathrm{C}_{22} \mathrm{H}_{46}$ & 310,61 & 49,83 & 49,79 & - & - & - \\
\hline Tricosan & $\mathrm{C}_{23} \mathrm{H}_{48}$ & 324,63 & 51,53 & 51,47 & - & 51,40 & - \\
\hline Tetracosane & $\mathrm{C}_{24} \mathrm{H}_{50}$ & 338,66 & 53,17 & 53,09 & - & 53,01 & - \\
\hline Pentacosane & $\mathrm{C}_{25} \mathrm{H}_{52}$ & 352,69 & 54,72 & 54,64 & - & 54,57 & - \\
\hline Hexacosane & $\mathrm{C}_{26} \mathrm{H}_{54}$ & 366,71 & 56,20 & 56,12 & - & 56,05 & - \\
\hline Heptacosane & $\mathrm{C}_{27} \mathrm{H}_{56}$ & 380,74 & 57,62 & 57,55 & - & 57,48 & - \\
\hline Octacosane & $\mathrm{C}_{28} \mathrm{H}_{58}$ & 394,77 & 58,98 & 58,92 & - & 58,86 & - \\
\hline Nonacosane & $\mathrm{C}_{29} \mathrm{H}_{60}$ & 408,79 & 60,28 & 60,24 & - & - & - \\
\hline Triacontane & $\mathrm{C}_{30} \mathrm{H}_{62}$ & 422,82 & 61,54 & 61,52 & - & - & - \\
\hline Hentriacontane & $\mathrm{C}_{31} \mathrm{H}_{64}$ & 436,85 & 62,77 & 62,75 & - & - & - \\
\hline Dotriacontane & $\mathrm{C}_{32} \mathrm{H}_{66}$ & 450,87 & 63,97 & 63,96 & - & - & - \\
\hline Tritriacontane & $\mathrm{C}_{33} \mathrm{H}_{68}$ & 464,90 & 65,13 & - & - & - & - \\
\hline Squalene & $\mathrm{C}_{30} \mathrm{H}_{50}$ & 410,71 & - & - & - & - & 59,27 \\
\hline \multicolumn{8}{|c|}{ Fatty acids ${ }^{b}$} \\
\hline Butanedioic acid & $\mathrm{C}_{4} \mathrm{H}_{6} \mathrm{O}_{4}$ & 118,08 & - & - & 10,47 & 10,52 & 10,57 \\
\hline Malic acid & $\mathrm{C}_{4} \mathrm{H}_{6} \mathrm{O}_{5}$ & 134,08 & - & - & - & 14,02 & 14,10 \\
\hline $\begin{array}{c}\text { D-Mannonic acid, } \gamma \text { - } \\
\text { lactone }\end{array}$ & $\mathrm{C}_{6} \mathrm{H}_{10} \mathrm{O}_{6}$ & 178,14 & - & - & - & - & 20,58 \\
\hline Benzoic acid & $\mathrm{C}_{13} \mathrm{H}_{22} \mathrm{O}_{3}$ & 282,48 & - & 17,655 & 19,47 & - & - \\
\hline Tetradecanoic acid & $\mathrm{C}_{14} \mathrm{H}_{28} \mathrm{O}_{2}$ & 228,37 & 19,94 & 19,94 & - & - & - \\
\hline Pentadecanoic acid & $\mathrm{C}_{18} \mathrm{H}_{38} \mathrm{O}_{2}$ & $\mathbf{3 1 4 , 5 7}$ & 21,28 & - & - & - & - \\
\hline Hexadecanoic acid & $\mathrm{C}_{16} \mathrm{H}_{32} \mathrm{O}_{2}$ & 256,42 & 22,58 & 22,60 & 22,54 & 22,54 & - \\
\hline Heptadecanoic acid & $\mathrm{C}_{17} \mathrm{H}_{34} \mathrm{O}_{2}$ & 270,45 & 23,74 & - & - & - & - \\
\hline Octadecanoic acid & $\mathrm{C}_{18} \mathrm{H}_{36} \mathrm{O}_{2}$ & 284,47 & 24,91 & - & 24,58 & - & - \\
\hline Eicosanoic acid & $\mathrm{C}_{23} \mathrm{H}_{48} \mathrm{O}_{2}$ & 384,71 & 27,03 & 27,03 & - & - & - \\
\hline Heneicosanoic acid & $\mathrm{C}_{24} \mathrm{H}_{50} \mathrm{O}_{2}$ & 398,73 & 28,04 & - & - & - & - \\
\hline Tricosanoic acid & $\mathrm{C}_{26} \mathrm{H}_{54} \mathrm{O}_{2}$ & 426,79 & 29,95 & - & - & - & - \\
\hline \multicolumn{8}{|c|}{ Phenols ${ }^{\text {st, }}$} \\
\hline Resorcinol & $\mathrm{C}_{6} \mathrm{H}_{4}(\mathrm{OH})_{2}$ & 110,11 & - & 30,72 & 31,74 & 31,513 & 30,55 \\
\hline $\begin{array}{c}\text { 2,4-bis(1,1- } \\
\text { dimethylethyl)- } \\
\text { Phenol }\end{array}$ & $\mathrm{C}_{14} \mathrm{H}_{22} \mathrm{O}$ & 206,32 & 36,08 & 36,12 & - & - & - \\
\hline $\begin{array}{c}\text { 2, 6, Dimethoxy } \\
\text { phenol }\end{array}$ & $\mathrm{C}_{8} \mathrm{H}_{10} \mathrm{O}_{3}$ & 154,16 & - & 32,29 & - & - & - \\
\hline $\begin{array}{c}\text { 3,4,5, Trimethoxy } \\
\text { phenol }\end{array}$ & $\mathrm{C}_{9} \mathrm{H}_{12} \mathrm{O}_{4}$ & 184,18 & - & 38,67 & - & - & - \\
\hline \multicolumn{8}{|c|}{ Aromatic compounds ${ }^{b}$} \\
\hline Benzaldehyd & $\mathrm{C}_{7} \mathrm{H}_{6} \mathrm{O}$ & 106,12 & - & - & 17,63 & - & - \\
\hline Umbelliferone & $\mathrm{C}_{9} \mathrm{H}_{6} \mathrm{O}_{3}$ & 162,14 & - & 20,309 & - & - & - \\
\hline \multicolumn{8}{|c|}{ Sterols $^{3, b}$} \\
\hline Campesterol & $\mathrm{C}_{28} \mathrm{H}_{48} \mathrm{O}$ & 400,68 & - & 34,76 & - & - & - \\
\hline B-Sitosterol & $\mathrm{C}_{29} \mathrm{H}_{50} \mathrm{O}$ & 414,71 & - & 66,21 & 66,21 & 66,17 & - \\
\hline
\end{tabular}


Higher hydrocarbons were only observed in the spectra of crude extractives, while fatty acids and aromatic compounds were limited to the spectra of derived ones. Phenols and sterols (specifically $\beta$-Sitosterol) were identified in spectra of both crude and derived extractives.

The removal order of different compounds by various solvents was almost relevant to the solvents' polarity. Higher hydrocarbons, being apolar and hydrophobic, were exhaustively extracted by HX, therefore there were considerably smaller traces of them in the successive spectra of DM (Figure 1b) and AC (Figure 1c), while none in that of ME (Figure 1d). The same happened with fatty acids, as they are much more abundant in the spectrum of HX than in those of the subsequent ones (Table 1). DM, as the second apolar solvent, has a stronger ability to reach different spots. It has been reported to have somehow the same swelling capacity as AC (Mantanis et al. 1994) and hence remove a portion of a diverse range of compounds present (alkanes, phenols and sterols). AC as an intermediary solvent could not extract apolar compounds and left the higher hydrocarbons untouched, removing only resorcinol and $\beta$-sitosterol. Interestingly, ME, being the second most polar solvent after water, could extract a combination of both polar and apolar compounds. It not only removed resorcinol and $\beta$-sitosterol, but also brought out a variety of heavy alkanes (mostly those of $\mathrm{C}_{23}$ to $\mathrm{C}_{28}$ ). Expectedly, $\beta$-sitosterol, being a hydrophobic compound, was not extracted by HW. The same happened for alkanes, as only one hydrocarbon (Squalene: $\mathrm{C}_{30} \mathrm{H}_{50}$ ) was found in the HW spectrum (Figure 2).

Phenols were observed to be the most occurring compound in the spectra of all solvents (whether crude or derived). Resorcinol $\left(\mathrm{C}_{6} \mathrm{H}_{4}(\mathrm{OH})_{2}\right)$, as the predominant phenol, was identified in the extractives removed by four solvents (with the exception of HX); first traced in the spectrum of DM, then intensely occurring in those of AC, ME and HW. Even when solvents were used successively, and by considering the pick of resorcinol in the spectrum of AC (Figure 1c), still, the pick is still visible in the spectrum of ME (Figure 1d).

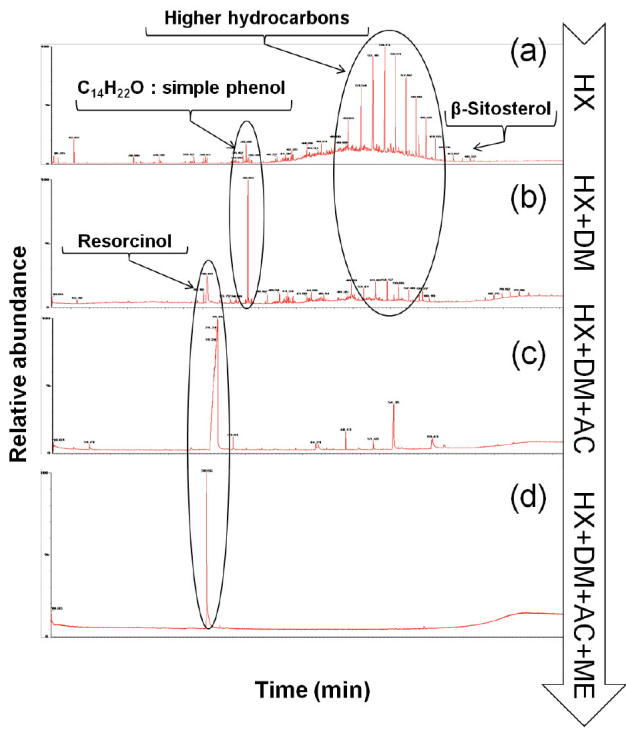

Figure 1. Mass spectra of cumulated crude extracts after four successive extractions: HX: Hexane, DM: Dichloromethane, AC: Acetone, Me: Methanol.

Note that it was not possible to solubilize the crude extractives after successive use of HW, the results thus are limited to the mass spectrum after individual submission to HW (Fig.2) and the compounds identified after siloxane derivation (Table 1). 
Some of the compounds observed in this study have already been reported previously: phenols and stilbenes of white mulberry were reported to be great chemotaxonomy markers (Venkataraman 1972, Rowe and Conner 1979). Rowe and Conner (1979) identified several flavonoids in both bark and wood of the mulberry. Deon et al. (1980) reported the same flavonoid (Morin) in Morus mesozygia. Recently other kinds of flavonoids and stilbenoids were identified in Bagassa guianensis, a species from the moraceae family (Royer et al. 2010). Interestingly, resorcinol and $\beta$-sitosterol, which are reported in this study, were also identified in Bagassa guianensis. The same two compounds were previously observed (Kulkarni et al. 1970, Rowe and Conner 1979); nevertheless neither of them has been the leading identified compound. Another recent study on the heartwood extractives of white mulberry from Iran (Sadeghifar et al. 2011) pointed to resorcinol as the leading compound ( $\approx 90 \%)$. This is consistent with the results of this study, where resorcinol showed the highest proportions.

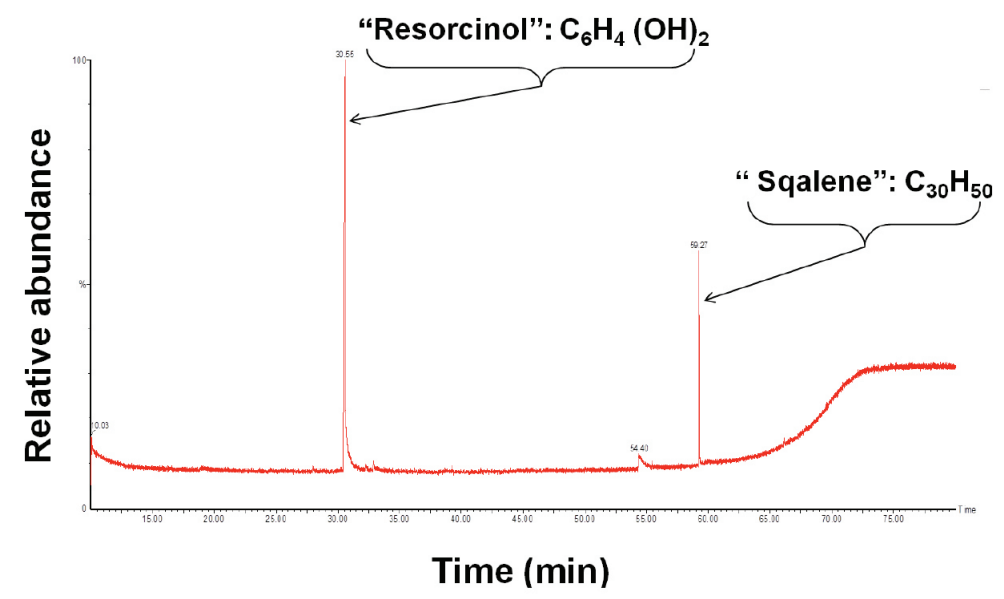

Figure 2. Mass spectrum of the cumulated crude extracts after independent use of hot water (HW).

\section{Survival rate of termites}

Figure 3 illustrates the survival rate of termites kept on extracted powder (3a) and the cumulated extractives (3b). 

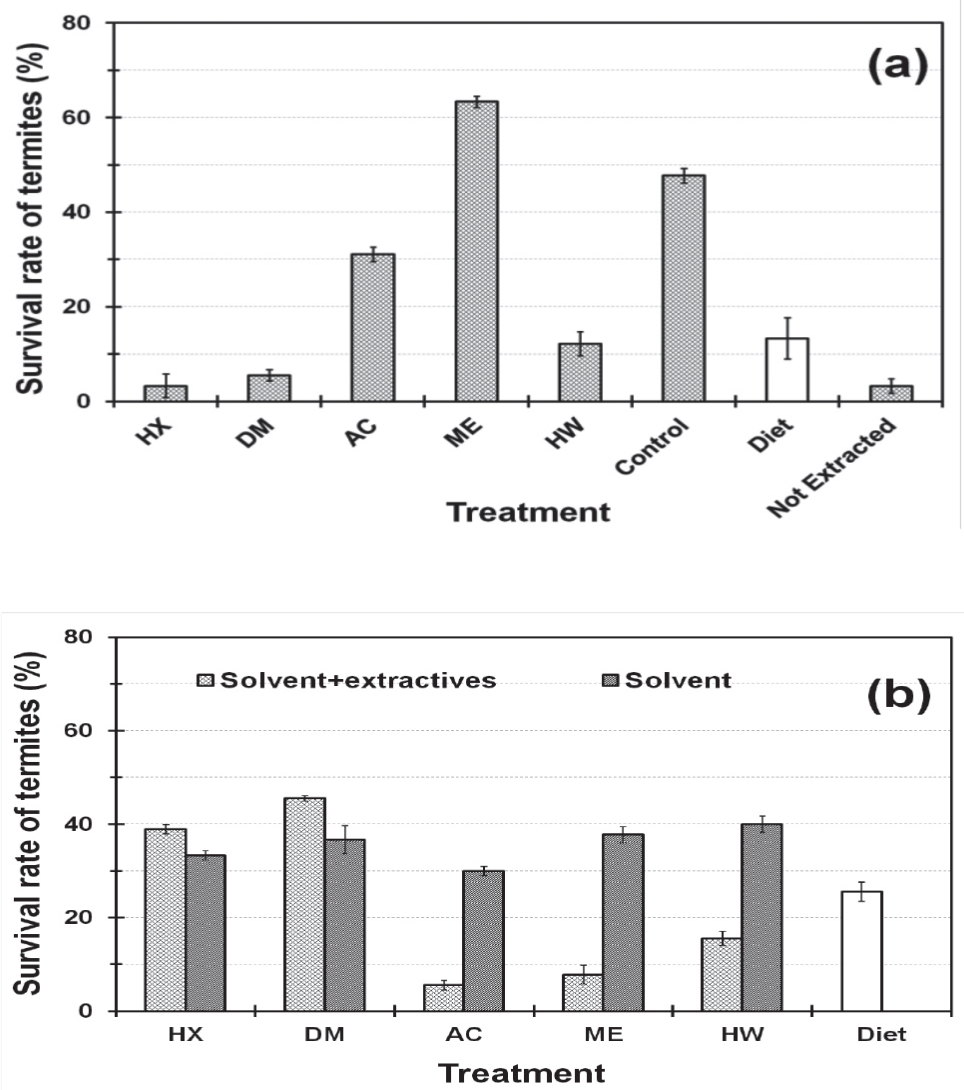

Figure 3. Survival rate of the termites (\%) in relation with the extracted powder (a) and cumulated extractives (b), solvent indications are as of before.

The small and similar survival rates of the termites exposed to of HX and DM-extracted powders with that of untreated one (Not extracted) (Figure 3a), indicate that despite the extraction, secondary compounds important for resistance towards decay agents remained intact inside the wood. The Notextracted powder result also correlates with what was previously reported on the natural durability of solid wood (Se Golpayegani et al. 2010). AC- extracted powder seems to have lost some of its effective extractives (as the survival rate was significantly higher than in the previous cases) but still had enough to exhibit only $\approx 30 \%$ survival rate. ME-extracted powder, on the other hand, having most of its extractives removed, showed the highest proportion of survived termites (survival rate $\approx 70 \%$ ). HW-extracted powder turned to have almost the same survival rate as in the sand-control dishes, where the termites died from starvation.

Using the cumulated extractives gave almost the same results as their powder (Figure 3b). Looking at the survival rates in connection with the solvents alone (darker bars on the right on Figure 2b), reveals that in case of apolar solvents (HX and DM) the small amounts of removed substances do not play any role in increasing resistance towards termites and the survival rates were approximately the same for extractive solutions and the solvents. In fact, when evaporated, solvents are not really effective on the termites (except maybe for AC). The similar survival rates of the solvents treated papers (HX, DM, and ME) with that treated with water is confirming the same fact. Here, the survival rate of the control (termites + cellulosic paper) was $48 \pm 2,5 \%$. Here again, the cumulated extractives after $\mathrm{ME}$ and $\mathrm{AC}$ extraction have the outmost effect on the termites survival rate. 
To allow a more detailed analysis, Figure 4 shows the amount of extractive content versus survival rate of termites. The raw material for this test came from the remaining powder after independent extraction, for which the amount of cumulated extracts were carefully noted and served for other analysis (Se Golpayegani et al. 2011). As the actual extractive contents were those of $3 \mathrm{~g}$ samples, here the results were extrapolated to match the $0,2 \mathrm{~g}$ samples of toxicity tests.

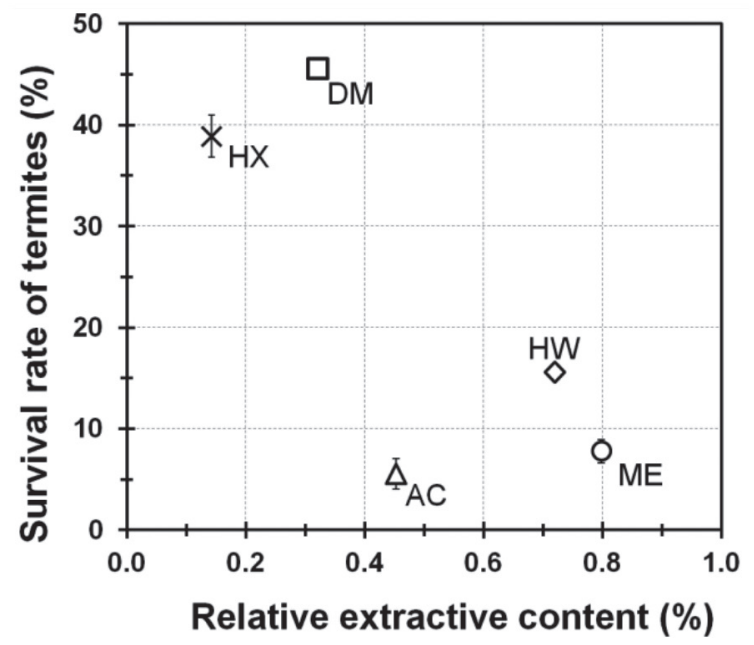

Figure 4. Survival rate of the termites when exposed to the cumulated extracts after extraction with different solvents in relation with the quantity of cumulated extracts after evaporation of each corresponding solvent.

Even though only a qualitative GC-Mass analysis was carried out in this study, Figure 4 suggests that the quantity of removed extracts is as important as their type and nature regarding their potential toxicity towards termites.

The extracts removed by two apolar solvents were of relatively minute quantities $(\approx 0,15 \%$ and $0,32 \%$ for HX and DM respectively), subsequently, they had little influence on the feeding ability of the termites and the survival rates were above $\approx 40 \%$. The three polar solvents, while bringing out higher amounts of extraneous compounds ( $\max \approx 0,79 \%$ for ME) seem to be able to remove effective component, resulting in a significantly lower survival rate.

\section{Connection between the identified compounds and survival rates of the termites}

Looking thoroughly at data presented in figures 3 and 4, two points could be retained: i) whatever type of extraneous compounds apolar solvents (HX and DM) were able to remove from white mulberry, apparently had no effect on its resistance towards termite attack.In contrast, for the three polar ones (AC, ME and HW); ii) the quantity of the removed extracts influences the resistance, as the three polar solvents are also removing much more amount of components than the apolar ones (Figure 4).

By connecting the statements above to the spectra presented in figures 1 and 2, we can synthesize:

1. Even though HX and DM remove a variety of higher hydrocarbons, phenols and sterols, they actually take out only a minimal amount of the extractives. These components have apparently only little/limited effect on the actual resistance towards termites.

2. The most visible and intense peak in the spectra of all three polar solvents, is that of resorcinol (Figure 1 and 2). Even if the extractives removed by the three polar solvents have slightly different effects on termites, still, they remain in a close range and far from the two apolar ones (Figure 3 and 4). 
3. From our results, resorcinol seems to be the compound responsible for the white mulberry resistance towards termites (Solely or in synergy with other compounds, as higher hydrocarbons are also found to have small roles in protecting the plants against decay resistance (Baker 1982).

Despite synthetic resorcinol has never been developed as a current active ingredient for wood protection, it has been reported in the early $20^{\text {th }}$ century as an anti-termite treatment (Lyons 1936). Resorcinol is used externally in ointments and lotions as an antifungal, and its preservative effects against basidiomycetes were previously established (Adikaram et al. 2010). Moreover, Yamaguchi et al. (2002) have shown that, amongst different tannin combinations, only resorcinolated mimosa tannins used as active ingredient in the wood caused $100 \%$ mortality of the very aggressive Coptotermes formosanus in an eating-damaged test.

Furthermore, resorcinol is listed as "harmful if digested", "irritant to skin and the eyes" and "dangerous to aquatic organisms" by technical and medical service of INRS (2000). If digested or exposed to skin in great quantities, it can cause health problems like headache, nausea and vomiting. Respiration difficulties (cough, short breath) were also seen among workers usually exposed to a mixture of resorcinol and 1 , 3, 5-tricyanomethyl hexahydro-s-triazine. However, the most effective component was not identified (Mastromatteo 1965). In France, 10ppm (or $45 \mathrm{mg} \mathrm{m}^{-3}$ ) is the maximum amount of resorcinol in the air allowed in a working environment. In addition to that, phenols (to which compounds most often found in white mulberry belong), are listed as dangerous in case of inhalation or digestion (INRS 2011).

The health problems reviewed above are similar to those reported by Iranian instrument makers. The saw dust released during carving could contain harmful substances (i.e. from phenol family) and cause allergic reactions. Phenols are easily absorbed by skin and cause irritations. However, most of the time, signs of the problems disappear after $24 \mathrm{~h}$, once the source of irritation is eliminated (INRS 2011). For an instrument maker, working solely on this species all day long and for several days in a row, the irritation source is always present. This is the reason why, when they give up working on this particular species, all signs of problem disappear.

\section{CONCLUSIONS}

Higher hydrocarbons, fatty acids, sterols and Phenols constitute the majority of the compounds found in white mulberry. Not all of them can be brought out by just one solvent, and their removal order corresponds almost entirely to the polarity of the solvents.

Extractives of white mulberry are toxic against decay termites. This toxic potential was observed to be related to both their nature and their crude abundance.

By correlating the GC-mass spectra of specific extractives to their termites survival rate, it was revealed that resorcinol $\left(\mathrm{C}_{6} \mathrm{H}_{4}(\mathrm{OH})_{2}\right)$, possibly along with other phenols, is the compound responsible for the health problems amongst Iranian instrument makers working (mainly) on this species.

\section{ACKNOWLEDGMENTS}

Authors are grateful to SCAC (Service de Coopération et d'Action Culturelle) of the French embassy in Tehran and ISMO (Iranian Center for International Research and Collaboration) for supporting this project. Authors are also grateful to Mr. Samad Zare, the professional Iranian lute maker who provided the raw material and shared his knowledge and experience through this study. 


\section{REFERENCES}

Adikaram, N.; Karunanayake, C.; Abayasekara, C.H. 2010. The role of pre-formed antifungal substances in the resistance of fruits to postharvest pathogens postharvest pathology. D. Prusky and M. L. Gullino, Postharvest Pathology 2:1-11.

Arango, A. R.; Green III, F.; Hintz, K.; Lebow, P.K.; Miller, R.B. 2006. Natural durability of tropical and native woods against termite damage by Reticulitermes flavipes (Kollar). International Biodeterioration and Biodegradation 57: 146-150.

Baker, E.A. 1982. Chemistry and morphology of plant epicuticular waxes. The Plant Cuticle, Academic Press, London, 139-165.

Chen, J.J.; Li, X.G. 2007. Hypolipidemic effect of flavonoids from mulberry leaves in triton WR-1339 induced hyperlipidemic mice. Asia Pacific J Clinical Nutrition 16: 290-294.

Croan, C. S.; Haight, J. 2001. Wood extractive concentration and sem examination of pretreated southern yellow pine wood chips with blue-stain fungi for mushroom production. IRG/WP 01-10407, International research group on wood preservation, 20-25 May, Nara, Japan.

Deon, G.; Chadenson, M.; Hautville, M. 1980. Influence of wood natural extractives on its decay resistance. (In French). Bois et Forêts des Tropiques 191:75-90.

El Hanbali, F.; Amusant, N.; Mellouki, F.; Akssira, M.; Baudasse, C. 2007. Potentiality of use extracts from Tetraclinis articulata like biocide against wood destroying organisms: Reticulitermes santonensis. IRG/WP 07-30418, International research group on wood preservation, 20-24 May, Jackson, USA.

Highley, T.L.; Scheffer, T.C. 1970. Natural Decay Resistance of 30 Peruvian Woods, Research Paper FPL 143. USDA Forest Service, Forest Products Laboratory, Madison WI. 4 p.

Hillis, W. E. 1962. Wood extractives and their significance to the pulp and paper industries, Academic Press, USA, 513p.

Hwang, W. J.; Kartal, S. N.; Yoshimura, T.; Imamura, Y. 2007. Synergistic effect of heartwood extractives and quaternary ammonium compounds on termite resistance of treated wood. Pest Management Science 63(1): 90-95.

National Institute of Research and Security. INRS. 2000. Technologic document $\mathrm{N}^{\circ} 178$ (Resorcinol). National institute of research and security for prevention of work accidents and professional sicknesses, France, $4 p$.

National Institute of Research and Security. INRS. 2011. Technologic document FT15 (Phenol). National institute of research and security for prevention of work accidents and professional sicknesses, France, 8p.

Kulkarni, D. D.; Ghugale, D. D.; Narasimhan, R. 1970. Chemical investigations of plant tissues grown in vitro: Isolation of $\beta$-sitosterol from Morus alba (mulberry) callus tissue. Indian J Exp Biol 8(4):347. 
Lyons, F.H. 1936. Impregnation composition for wood and the like. US. Patent 2,041,647, 1936.

Mantanis, G.I.; Young, R.A.; Rowell, R.M. 1994. Swelling of wood. Part II. Swelling in organic liquid. Holzforschung 48(6): 480-490.

Mastromatteo, E. 1965. Recent occupational health experiences in Ontario. J Occup Med (7): 5002-5011.

Nakamura, M.; Nakamura, S.; Oku, T. 2009. Suppressive response of confections containing the extractive from leaves of Morus alba on postprandial blood glucose and insulin in healthy human subjects. Nutrition and Metabolism 6:29.

Piao, S. J.; Qiu, F.; Chen, L.X.; Pan, Y.; Dou, D. Q. 2009. New Stilbene, Benzofuran, and Coumarin Glycosides from Morus alba. Helvetica Chimica Acta 92(3): 579-587.

Ragon, K. W.; Nicholas, D.D.; Schultz, T.P. 2008. Termite-Resistant Heartwood: The Effect of the Non-Biocidal Antioxidant Properties of the Extractives (Isoptera: Rhinotermitidae). Sociobiology 52 (1): 47-55.

Rowe, J.W.; Conner, A. 1979. Extractives in Eastern Hardwoods-A Review, Forest Products Laboratory, Forest Service, U.S. Department of Agriculture, Madison, Wisconsin, USA, 72 pp.

Royer, M.; Herbette, G.; Eparvier, V.; Beauchene, J.; Thibaut, B.; Stien, D. 2010. Secondary metabolites of Bagassa guianensis Aubl. wood: a study of the chemotaxonomy of the Moraceae family. Phytochemistry 71(1415): $1708-1713$.

Sadeghifar, H.; Sheikh, A.; Khalilzadeh, M.A.; Ebadi, A.GH. 2011. Heartwood Extractives of Iranian Morus alba Wood. J Chem Soc Pak 33(1): 104-106.

Schultz, T.P.; Nicolas, D.D. 2000. Naturally durable heartwood: evidence for a proposed dual defensive function of the extractives. Phytochemistry 54 (1): 47-52.

Se Golpayegani, A. 2007. Primary evaluation of mulberry's wood (Morus alba L.). Master thesis (in Farsi), University of Tehran, Iran, 150p.

Se Golpayegani, A.; Thevenon, M.F.; Gril, J. ; Pourtahmasi, K. 2010. Natural durability of white mulberry (Morus alba L.). $4^{\text {th }}$ international research group of wood preservation (IRG), 9-13 may, Biarritz, France.

Se Golpayegani, A.; Bremaud, I.; Gril, J.; Thevenon, M.F.; Arnould, O.; Pourtahmasi k. 2011. Effect of extractions on dynamic mechanical properties of white mulberry (Morus alba L.). J Wood Sci 58 (2): 153-162.

Se Golpayegani, A. 2011. Characterization of mulberry's wood (Morus alba L.), considering its usage in making Iranian lute, Ph.D. Thesis, Montpellier II University, France, 288p.

TAPPI STANDARD. 2007. T204cm-07, T.S.m. Solvent extractives of wood and pulp. Technical Assiciation of the Pulp and Paper Industry, USA. 
Taylor, A.M.; Gartner, B.L.; Morrell, J.J. 2002. Heartwood formation and natural durability-A review. Wood Fiber Sci (34):587-611.

Thevenon, M.F.; Simonin, P.; Carrer, A.; Fouqut, D. 2003. Evaluation of Rosewood extractives as potential source for termite control. IRG/WP 03-30323, International research group on wood preservation. 18-23 May, Brisbane, Australia.

Tsunoda, K. 1990. The natural resistance of tropical woods against biodeterioration. Bulletin of Wood Research Institute of Kyoto University (77): 18-27.

Turner, P.; Conradie, D. 1995. The chemical analysis and biological evaluation of wood extractives as potential timber preservatives. IRG/WP 95-30090, International research group on wood preservation, 11-16 May, Helsinki, Denmark.

Venkataraman, K. 1972. Wood phenolics in the chemotaxonomy of the moraceae. Phytochemistry (11): 1571-1586.

Yamaguchi, H.; Yoshino, K.; Kido, A. 2002. Termite resistance and wood penetrability of chemically modified tannin and tannin-copper complexes as wood preservatives. J Wood Sci (48): 331-337

Yatsunami, K.; Ichida, M.; Onodera, S. 2008. The relationship between 1- deoxynojirimycin content and a-glucosidase inhibitory activity in leaves of 276 mulberry cultivars (Morus spp.) in Kyoto. Japan J Nat Med (62): 63-66.

Zheng, Z.P.; Cheng, K.W.; Zhu, Q.; Wang, X.C.; Lin, Z.X.; Wang, M. 2010. Tyroinase inhibitory constituents from the roots of Morus nigra: Structure-activity relationship study. J Agric Food Chem (58): 5368-5373. 